\title{
Recurrent Ewing Sarcoma
}

National Cancer Institute

\section{Source}

National Cancer Institute. Recurrent Ewing Sarcoma. NCI Thesaurus. Code C7808.

Ewing sarcoma which has recurred after treatment and/or remission. While initial complete responses are not uncommon, there is a fair chance of relapse as late as one to two decades after initial therapy. 